Article

\title{
New Insights into Health Risk Assessments for Inhalational Exposure to Metal(loid)s: The Application of Aqueous Chemistry Modelling in Understanding Bioaccessibility from Airborne Particulate Matter
}

\author{
Michael E. Deary ${ }^{1, *(\mathbb{D})}$, Patrick M. Amaibi ${ }^{2}$, John R. Dean ${ }^{2}$ (D) and Jane A. Entwistle ${ }^{1(D)}$ \\ 1 Department of Geography and Environmental Sciences, Northumbria University, \\ Newcastle upon Tyne NE1 8ST, UK; jane.entwistle@northumbria.ac.uk \\ 2 Department of Applied Sciences, Northumbria University, Newcastle upon Tyne NE1 8ST, UK; \\ atrik2k7@gmail.com (P.M.A.); john.dean@northumbria.ac.uk (J.R.D.) \\ * Correspondence: michael.deary@northumbria.ac.uk
}

Citation: Deary, M.E.; Amaibi, P.M.; Dean, J.R.; Entwistle, J.A. New

Insights into Health Risk Assessments for Inhalational Exposure to Metal(loid)s: The Application of Aqueous Chemistry Modelling in Understanding Bioaccessibility from Airborne Particulate Matter. Geosciences 2021, 11, 47. https:// doi.org/10.3390/geosciences11020047

Received: 29 December 2020

Accepted: 19 January 2021

Published: 23 January 2021

Publisher's Note: MDPI stays neutral with regard to jurisdictional claims in published maps and institutional affiliations.

Copyright: (c) 2021 by the authors. Licensee MDPI, Basel, Switzerland. This article is an open access article distributed under the terms and conditions of the Creative Commons Attribution (CC BY) license (https:// creativecommons.org/licenses/by/ $4.0 /)$.

\begin{abstract}
Aqueous modelling of chemical speciation in simulated lung fluid (SLF) enables a better understanding of the underlying chemical factors that influence metal(loid) inhalation bioaccessibility from airborne particulate matter. Such an approach can be used to supplement experimental techniques that are integral to the health risk assessment of metal(loid) exposure by inhalational routes. In this paper, we modelled the aqueous chemistry of airborne particulate-bound metal(loid)s (As, $\mathrm{Cu}, \mathrm{Mn}, \mathrm{Pb}$ and $\mathrm{Zn}$ ) in a SLF based on Gamble's solution (neutral $\mathrm{pH}$ ). The modelling was performed using two software packages (Geochemist's Workbench 14 and OLI Studio 9.5) and a total of five thermochemical databases (GWB Thermo, MINTEQ, PHREEQC, WATEQ4F and the default database for OLI Studio). Modelled results were compared with experimentally determined bioaccessibilities for the NIST 2710a standard reference material (SRM) and with literature-reported bioaccessibilities for NIST 1648a and BCR 038 SRMs. Whilst the models correctly describe the observed increase in bioaccessibility for more dilute solid/liquid extraction ratios, the performance of the models against the fractional bias of the mean $\left(F B_{\text {mean }}\right)$ and the normalised mean square error (NMSE) statistical metrics was generally outside the acceptance criteria. Findings from an analysis of the main aqueous chemical species predicted to be present in SLF indicate that carbonate and chloride complexes of $\mathrm{Cu}, \mathrm{Mn}, \mathrm{Pb}$ and $\mathrm{Zn}$ predominate, whilst free cations (for $\mathrm{Cu}, \mathrm{Mn}$ and $\mathrm{Zn}$ ) and hydroxides (for $\mathrm{Cu}$ ) also play a role in solubilisation. Arsenic is not predicted to form significant complexes with the SLF components and is present in solution mainly as the $\mathrm{HAsO}_{4}{ }^{2-}$ ion and its conjugate acid, $\mathrm{H}_{2} \mathrm{AsO}_{4}{ }^{-}$. For modelled runs where glycine and citrate were present, significant increases in the bioavailability of $\mathrm{Cu}$ and $\mathrm{Zn}$ were predicted as a result of complexation with these ligands. An additional finding from our experimental bioaccessibility results for NIST 2710a was that the inclusion of the lung fluid surfactant dipalmitoylphosphatidylcholine (DPPC) in the SLF did not significantly affect the bioaccessibility. Our study provides useful insights into the likely aqueousand solid-phase speciation of metal(loid)s in SLF and highlights that future developments in this area should consider the role of mineralogy and surface interactions.
\end{abstract}

Keywords: inhalation bioaccessibility; PTEs; metal(loid)s; simulated lung fluid; MINTEQ; PHREEQC; WATEQ4F; Geochemist's Workbench; OLI Studio

\section{Introduction}

Inhalation of particulate matter (PM), especially the finer fractions, can contribute to adverse health outcomes, including increased incidence of allergies, asthma, bronchitis, emphysema and cancers [1]. Moreover, it is known that the metal and metalloid components of the particulates are also associated with these health effects [1,2]. Upon inhalation, fine particulate fractions, i.e., those with an aerodynamic diameter less than $4 \mu \mathrm{m}$, are most 
likely to deposit in the alveoli [3], whereas larger particulates may become impacted upon the mucous-lined surfaces of the nasopharynx and tracheobronchial regions of the respiratory tract [4]. These different deposition locations determine the residence time of the particle in the lungs and the composition of the lung fluid into which bound contaminants, such as metals/metalloids, might be extracted [5]. If deposited in the tracheobronchial regions, it is estimated that mucociliary clearance will occur at a rate of $1-2 \%$ per minute, giving a half-life for the deposited particles of 1-2 $\mathrm{h}$ [5], a figure that is supported by a finding that only 10-15\% of particles remain in the tracheobronchial region after $24 \mathrm{~h} \mathrm{[6].}$ However, particles that are deposited in the alveolar regions of the lung are known to have a considerably greater residence time, with half-lives as high as 300 days [6], thus allowing for longer-term interaction between the particle and lung fluid. Once solubilised, there is potential for direct transfer of contaminants to the blood stream [7], where a range of toxic effects may be exerted on the organs of the body, including carcinogenicity (As, Cd, $\mathrm{Cr}(\mathrm{VI}), \mathrm{Ni})$, neurological effects $(\mathrm{Pb}$ and $\mathrm{Hg}$ ) and renal damage $(\mathrm{Cr}, \mathrm{Cd}, \mathrm{Hg})$ [2]. In addition, solubilised and surface-bound metals may participate in Fenton and Fenton-like chemical reactions to generate reactive oxygen species (ROS) [2,8]. This generation of ROS, in addition to free radicals produced by the alveolar macrophages, gives rise to oxidative stress, and may cause a subsequent inflammatory response in the body [2,9]. The degree to which such effects manifest is dependent on the 'release bioaccessibility' [7] of the metals and metalloid (henceforth potentially toxic elements, or PTEs) components of the particles, i.e., the fraction of particle-bound PTEs that is released during the time that the particle interacts with lung fluids. A related bioaccessibility term is 'deposition bioaccessibility', which refers to the proportion of total inhaled atmospheric particles that are retained by the respiratory tract, i.e., that are not subsequently exhaled [10]. Depositional bioaccessibility depends on the region of the lungs into which the particulates are deposited and, for each region, on the size of the particulates [11]. For example, in the alveoli, it is estimated that $50 \%$ of inhaled particles of diameter $0.02 \mu \mathrm{m}$ (ultrafine particles) are deposited, whereas the proportion of particles deposited falls to between $10 \%$ and $1 \%$ for 1 to $10 \mu \mathrm{m}$ diameter particles [10].

Release bioaccessibility, which we will refer to as 'bioaccessibility' henceforth (but noting the importance of depositional bioaccessibility), is dependent on many factors, but predominantly on (i) the residence time in the lungs, (ii) the composition of the lung fluid to which the particle is predominantly exposed, and (iii) the chemical form of the bound PTEs. Lung fluid is not of a homogeneous composition. The pH-neutral extracellular fluids of the lung linings are dominated by phospholipids, salts, proteins, organic acids and surfactant. In the tracheobronchial regions, there will also be a mucous layer that sits on top of the extracellular lung fluid layer and into which the particles will initially impact. In the alveolar regions, in addition to the neutral epithelial fluid, particles may be subject to phagocytosis by alveolar macrophages, exposing them to an acidic lysosomal environment. The complexities of determining likely durations of exposure to the different lung fluid compositions for different sized particles has highlighted the need for a unified inhalational bioaccessibility protocol, as exists for oral bioaccessibility $[7,12]$.

The range of different artificial lung fluids used in the literature makes it difficult to directly compare bioaccessibility between different studies [12]. Ren et al. [7] and Kastury et al. [13] have recently reviewed the development of inhalational bioaccessibility tests and fluids. The fluids can be categorised according to the regions of the lung that they are mimicking. Gamble's and modified Gamble's (with dipalmitoylphosphatidylcholine (DPPC) surfactant and other components such as mucin [12]) solutions simulate neutral ( $\mathrm{pH}$ 7.3) extracellular fluids, though formulations vary in their inclusion of certain amino acids such as glycine and cysteine $[7,8,14,15]$, which are known to chelate with metals $[8,15]$. A variant of Gamble's solution, Hatch's solution, simulates the influence of the mucous component that is likely to be prevalent in the tracheobronchial region of the lungs, with the inclusion of protein and enzyme components [7]. Generically, these neutral fluids are known as simulated lung fluids (SLFs). 
A harsher extraction environment for PTEs is provided by artificial lung fluids that simulate phagocytosis, i.e., the engulfment of particles by alveolar macrophages. The macrophage lysosomal fluids contain proteases and bacterial enzymes and are at a much lower $\mathrm{pH}$ than the extracellular lung fluids, typically $\mathrm{pH} 4.5$ [14]. These conditions are simulated in artificial lysosomal fluids (ALFs) by the inclusion of glycine, citrate, pyruvate, tartrate, and lactate $[7,14,15]$.

There are contrasting literature opinions as to whether the more conservative ALF should be used to assess bioaccessibility $[14,15]$ or whether uncertainty about the proportion of time that a particle is resident in lysosomal fluid means that SLF is a more realistic extraction fluid [4]. The choice is important because bioaccessibility is generally much higher in ALF compared to SLF and, in some studies, reported to be as high as $100 \%$ for $\mathrm{Pb}, \mathrm{Cu}$ and $\mathrm{As}$ [15]. For example, bioaccessibility of $\mathrm{Pb}$ in three standards, BCR 723, NIST 2710a and NIST 1648a, ranged from 51 to $76 \%$ in ALF compared to 7.1 to $11.9 \%$ in modified Gamble's solution [14]. Nevertheless, the difference was less pronounced for $\mathrm{Mn}, \mathrm{Cu}$ and $\mathrm{Zn}$, while for $\mathrm{Cd}$ and $\mathrm{Co}$, the extractabilities were similar for the two fluids and, in some cases, higher for modified Gamble's solution.

The chemical nature of the PTE components of the deposited particles also plays a significant role in its bioaccessibility, with several studies reporting the role played by mineralogy and speciation $[3,13,14,16]$. Such observations, for example that particles containing $\mathrm{Pb}$ in the form of galena $(\mathrm{PbS})$ give lower inhalational bioaccessibilities than those containing $\mathrm{Pb}$ as anglesite $\left(\mathrm{PbSO}_{4}\right)$ [13], imply that bioaccessibility is likely to be highly source dependent. This conclusion is nicely demonstrated by the range of bioaccessibilities found by Caboche et al. [8] using Gamble's solution for standard reference materials (SRMs) representing: (i) urban particulates (NIST 1648a: Cd, 56\%; $\mathrm{Cu}, 41 \%$; Ni, 28\%; $\mathrm{Pb}, 14 \%$; and $\mathrm{Zn}, 75 \%$ ); (ii) vehicle exhaust particulates (NIES 8: Cd, 93\%; Cu, 37\%; $\mathrm{Ni}, 59 \%$; $\mathrm{Pb}$, $45 \%$; and $\mathrm{Zn}, 92 \%$ ); (iii) fly ash (BCR 038: Cd, $22 \%$; $\mathrm{Cu}, 36 \%$; $\mathrm{Ni}, 16 \%$; $\mathrm{Pb}, 3 \%$; and $\mathrm{Zn}$, $21 \%$ ); and (iv) vacuum cleaner (indoor) dust (NIST 2584: Cd, $41 \% ; \mathrm{Cu}, 41 \% ; \mathrm{Ni}, 43 \%$; $\mathrm{Pb}, 24 \%$; and $\mathrm{Zn}, 52 \%)$ [8]. Of note from this data are the large variations in $\mathrm{Pb}(2 \%$ to $45 \%), \mathrm{Zn}(21 \%$ to $92 \%)$ and $\mathrm{Cd}(22 \%$ to $92 \%)$. For Pb in urban street dust, Dean et al. found bioaccessibility to be less than $8.8 \%$, using modified Gamble's solution [4]. Liu et al. also found widely varying bioaccessibilities depending on source [1] and the review by Ren et al. [7] highlights the wide range of reported bioaccessibilities for an array of PTEs. Sources may also change, in terms of metal speciation, over time because of weathering; this is particularly relevant to particulates generated from mining [16-18] and smelting [19] wastes. Other factors that have been considered to affect bioaccessibility are dissolution kinetics [17], surface reactions and complexation [20,21], redox reactions [3], particle size and shape $[15,19]$ and the solid to liquid ratio (S/L ratio) $[8,14]$. Of these factors, $\mathrm{S} / \mathrm{L}$ ratio and the potential for surface complexation are likely to have the most significant influence on the \% bioaccessibility.

There has been much literature debate about the appropriate $\mathrm{S} / \mathrm{L}(\mathrm{g} / \mathrm{mL})$ to use in simulated lung fluid extractions [7], and several authors have calculated the likely range of these values $[8,14]$. Some studies have opted to carry out extractions over a wide range of values, for example Caboche et al. [8], who used a range of $1 / 30$ to $1 / 50,000$ and Pelfrêne et al., who used a range of $1 / 1000$ to $1 / 10,000$ [14]. This approach is a sensible one because the ratio will be dependent on a wide range of factors, including concentration of airborne particulates and deposition location. However, the chosen ratio has been shown to influence bioaccessibility, for example by Caboche et al., who found significantly lower proportions of bioaccessible $\mathrm{Pb}$ and $\mathrm{Zn}$ at an $\mathrm{S} / \mathrm{L}$ ratio of $1 / 30$ compared to 1/500 [8]. The lower bioaccessibilities at more concentrated extraction conditions have been ascribed to the saturation of species in solution and a restricted exposure of particulate surface to the extractant medium [8].

Another significant factor affecting bioaccessibility is the possibility of occlusion of the particulate surface because of the formation of surface complexes, which may limit the extent of dissolution of particle components. Wragg and Klinck [21] and Kastury et al. [20] 
have both demonstrated that coatings ( $2-5 \mu \mathrm{m}$ thick) of $\mathrm{Pb}$ phosphates form as a result of $\mathrm{Pb}$ complexing with phosphate from the neutral SLFs (Pb-Si-P-Al-O in the case of Wragg and Klinck [21] in Gamble's solution and O-Pb-Ca-P-Si-Al-Fe in the case of Kastury et al. in Hatch's solution [20]). The same coatings are not observed with the ALF, where such complexation is thought unlikely to occur at the lower $\mathrm{pH}$ [20].

A more thorough understanding of the aqueous chemistry of PTEs in SLF may help in the prediction of bioaccessibility. Therefore, in this paper, we compare the performance of two aqueous chemistry modelling packages and a total of five thermochemical databases in predicting the equilibrium concentrations of PTE components of the particles when subjected to SLFs, i.e., to compare modelled against observed bioaccessibilities. Data for observed bioaccessibilities are provided by our own experimental determination for NIST 2710a and literature bioaccessibilities values for NIST 1648a and BCR 038 [8]. Moreover, we analyse the aqueous- and solid-phase chemical species that are predicted to be present, and the insights that this provides for PTE bioaccessibility. There are literature examples of aqueous chemistry modelling being applied to a range of related environmental scenarios, such as in the prediction of speciation and solubility of metals and metalloids during leaching from smelter fly ash $[19,22-24]$ and mine tailings [16,17], and in assessing the impact of acid rain on weathering and $\mathrm{Al}^{3+}$ release in Swedish conifer forests [25]. Specific applications involving bioaccessibility modelling have included the simulation of speciation and solubility of PTEs from mine tailings in simulated lung and gut fluids [16] and the dissolution of uranium from particulates in simulated lung fluids [3]. Most of these studies have used the PHREEQC geochemical modeler [26], with either the MINTEQ [3,17,19,22,23,27] or WATEQ4F [18] thermochemical databases [27,28]. Geochemist's Workbench (GWB) has also been used, with its built-in Thermo thermochemical database [16]. The MINTEQ (3383 aqueous species, 709 minerals, 12 gases [27]), PHREEQC (187 aqueous species, 57 minerals, 8 gases [26]) and WATEQ4F (361 aqueous species, 310 minerals, 8 gases [28]) thermochemical databases are all available through the GWB 14 interface, along with the built-in Thermo database (647 aqueous species, 624 minerals, 10 gases [29]), and are all used in this paper. In addition, we compare predicted bioaccessibilities using another geochemical modelling package, OLI Studio, and its built-in thermochemical framework (80 inorganic elements of the periodic table, and their associated aqueous species, as well as over 8000 organic species) [30]. As far as we are aware, this package has not been applied to the prediction of bioaccessibility, though it has been used in environmental applications [31-33].

\section{Materials and Methods}

\subsection{Experimental Determination of Inhalation Bioaccessibility of $\mathrm{As}, \mathrm{Cu}, \mathrm{Mn}, \mathrm{Pb}$ and $\mathrm{Zn}$ from NIST $2710 a$}

The observed bioaccessibility of PTEs from NIST 2710a was determined for triplicate samples using the Gamble's solution formulation of Caboche et al.: $\mathrm{NaCl}, 6400 \mathrm{mg} \mathrm{L}^{-1}$; $\mathrm{CaCl}_{2} \cdot 2 \mathrm{H}_{2} \mathrm{O}, 255 \mathrm{mg} \mathrm{L}^{-1} ; \mathrm{Na}_{2} \mathrm{HPO}_{4}, 150 \mathrm{mg} \mathrm{L}^{-1} ; \mathrm{NaHCO}_{3}, 2700 \mathrm{mg} \mathrm{L}^{-1} ; \mathrm{Na}_{3}$ citrate $2 \mathrm{H}_{2} \mathrm{O}$, $160 \mathrm{mg} \mathrm{L}^{-1} ; \mathrm{NH}_{4} \mathrm{Cl}, 118 \mathrm{mg} \mathrm{L}^{-1}$; Glycine, $190 \mathrm{mg} \mathrm{L}^{-1}$ [8]. However, a modification was that the bioaccessibility determinations were made in the presence and absence of DPPC $(0.02 \%)$ in order to test the effect of lung fluid surfactants on bioaccessibility; these are thought to aid wettability of particles and prevent aggregation [8]. Appropriate sample weights of powdered standard reference material (SRM) to achieve the desired range of $\mathrm{S} / \mathrm{L}\left(\mathrm{g} \mathrm{mL}^{-1}\right)$ ratios $(1 / 30,1 / 500,1 / 2000$ and $1 / 4000)$ were mixed with a fixed volume of $30 \mathrm{~mL}$ of SLF. The extraction solutions were then placed on an end-over-end shaker at $37^{\circ} \mathrm{C}$, and 40 rotations per minute, for $24 \mathrm{~h}$. The extract was centrifuged at $14,600 \mathrm{rpm}$ for $20 \mathrm{~min}$. The supernatant was then removed, and $100 \mu \mathrm{L}$ of concentrated nitric acid added and the resultant solution refrigerated at $4{ }^{\circ} \mathrm{C}$ until analysed. For analysis, $9 \mathrm{~mL}$ of the acidified extract was placed in a tube and $1 \mathrm{~mL}$ of internal standard (Sc) added.

The total PTE concentration in NIST 2710a was determined using microwave digestion according to the method of Okorie et al. [34]. A soil sample $(0.5 \mathrm{~g})$ was accurately weighed into a PTFE (Teflon) vessel pre-cleaned with $10 \% \mathrm{HNO}_{3}$ solution. Then, $13 \mathrm{~mL}$ of aqua 
regia was added to the sample in a fume hood. The vessels were sealed and placed in the microwave carousel for microwave digestion. The microwave-assisted digestion was achieved using a closed vessel microwave-accelerated reaction system (MARS 5, CEM Corporation). This instrument was set at a power of 440 Watts for $40 \mathrm{~min}$, with a cooling time of $20 \mathrm{~min}$. The maximum pressure and temperature allowed for the XP-1500 vessel ranged from 100 to $600 \mathrm{psi}$ and 240 to $300^{\circ} \mathrm{C}$, respectively. After cooling, the digest was filtered through the filter paper into a $50 \mathrm{~mL}$ volumetric flask and made up to the mark with deionised water. Finally, this solution was transferred into a $50 \mathrm{~mL}$ screw-cap Sarstedt tube ready for ICP-AES analysis. For analysis of the samples, aliquots of the NIST 2710a extracts, blanks and calibration solutions were prepared by adding a Sc solution (1 ppm) as an internal standard and diluted with $1 \% \mathrm{HNO}_{3}$ solution to ensure that the solutions are of similar matrix with the standard calibration solutions. Approximately $0.1-5 \mathrm{~mL}$ of the digested solution was diluted in a $10 \mathrm{~mL}$ tube with $1 \mathrm{~mL}$ of internal standard added. The volume was made up to $10 \mathrm{~mL}$ with $1 \% \mathrm{HNO}_{3}$ solution before the ICP-AES analysis.

The ICP-AES instrument (PerkinElmer Optima-8000, Beaconsfield, UK) was calibrated with a range of concentrations- $0.01,0.1,1,2,5,10,20 \mathrm{mg} \mathrm{L}^{-1}$ - and a calibration blank prepared from a multi-element calibration solution. A linear calibration curve was achieved with good correlation coefficient $\left(R^{2}>0.9999\right)$ for each of the analytes. Prior to analysis of the sample, a suitable wavelength for each element was selected to avoid chemical interferences. All elemental concentrations were reported as $\mathrm{mg} \mathrm{kg}^{-1}$, dry weight. The ICP-AES operating conditions for the plasma were as follows: RF power, 1300 watts; RF frequency, $40 \mathrm{MHz}$; nebuliser flow, $0.55 \mathrm{~L} \mathrm{~min}^{-1}$; auxiliary flow, $0.2 \mathrm{~L} \mathrm{~min}^{-1}$; plasma flow, $15 \mathrm{~L} \mathrm{~min}^{-1}$; equilibrium time, $15 \mathrm{~s}$; plasma aerosol type, wet; nebuliser start-up conditions, gradual; plasma view, axial. The peristaltic pump conditions were as follows: sample flow rate, 1.5 $\mathrm{L} \mathrm{min}^{-1}$; sample flush time, $30 \mathrm{~s}$; wash rate, $2.00 \mathrm{~mL} \mathrm{~min}^{-1}$; wash time, $60 \mathrm{~s}$; read delay, $2 \mathrm{~s}$; replicates, 3; background correction, 2 points (for all elements).

\subsection{Aqueous Chemistry Simulation}

Aqueous chemistry simulations were carried out using two software packages: GWB 14 and OLI Studio 9.5. For both packages, and for all thermochemical databases used, a basic aqueous chemistry simulation was used, whereby it is assumed that all species are initially in the aqueous state, and the calculation is then made of the likely solid states (precipitates) that form, and thus the equilibrium aqueous species that remain. Whilst the models can also simulate surface adsorption and redox reactions, neither of these options were used.

\subsubsection{Aqueous Chemistry Simulation Using GWB 14}

For the GWB 14 aqueous chemistry modelling, spreadsheets of concentrations for the 'basis' species (the initial aqueous species present prior to any calculation of complexes and precipitates [35]) were prepared for each of the thermochemical datasets used: Thermo, PHREEQC, WATEQ4F and MINTEQ. Some of these thermochemical datasets had a reduced number of available chemical species; for example, WATEQ4F and PHREEQC do not include $\mathrm{Cr}$ or $\mathrm{Hg}$ species and, PHREEQC does not include $\mathrm{As} \mathrm{Cr}$, $\mathrm{Hg}$ or Ni species. Furthermore, only MINTEQ contains the glycine and citrate species that are used in Gamble's solution, and none contain the surfactant DPPC. The calculation of the concentration of the initial aqueous species in $1 \mathrm{~L}$ of water was made on the basis of (a) the components of the Gamble's extraction solution; (b) the concentrations given in the certificate of analysis for the SRMs (NIST 2710a was used for our extractability work; while NIST 1648a and BCR 038 were used to compare with the extractability data of Caboche et al. [8]); and (c) the S/L ratio being modelled $(1 / 30,1 / 500,1 / 2000$ and $1 / 4000$ to compare with the experimental extraction results obtained in the present paper, with the addition of $1 / 20,000$ and $1 / 50,000$ to compare with the literature extractability data [8]).

Thus, with the exceptions stated above, the species specified in the basis sets were $\mathrm{Al}^{3+}, \mathrm{H}_{2} \mathrm{AsO}_{4}{ }^{-}, \mathrm{Br}^{-}, \mathrm{Ca}^{2+}, \mathrm{Cl}^{-}, \mathrm{Cu}^{2+}, \mathrm{Fe}^{3+}, \mathrm{Pb}^{2+}, \mathrm{Hg}^{+}, \mathrm{Mg}^{2+}, \mathrm{Mn}^{2+}, \mathrm{Ni}^{2+}, \mathrm{K}^{+}, \mathrm{H}_{4} \mathrm{SiO}_{4}$, 
$\mathrm{Na}^{+}, \mathrm{Sr}^{2+}, \mathrm{SO}_{4}{ }^{2-}, \mathrm{Zn}^{2+}, \mathrm{PO}_{4}{ }^{3-}, \mathrm{CO}_{3}{ }^{2-}$ and $\mathrm{NH}_{4}{ }^{+}$. In addition, separate modelling runs were carried out using MINTEQ in the absence and presence of citrate and glycine. The specified physical conditions were $\mathrm{pH} 7.4$ and $37^{\circ} \mathrm{C}$, corresponding to the experimental extraction conditions used to replicate the situation in the human lung.

Once specified, the equilibrium concentrations of the aqueous species were calculated using the GWB React program. Prior to running React, three of the aqueous species needed to be substituted with mineral species in order to constrain the model [35]: quartz replacing $\mathrm{H}_{4} \mathrm{SiO}_{4}$, hematite replacing $\mathrm{Fe}^{3+}$ and gibbsite replacing $\mathrm{Al}^{3+}$. The charge balance species was set to $\mathrm{Cl}^{-}$, and precipitation reactions were enabled. For the main set of modelling runs, the final $\mathrm{pH}$ of the solution was calculated by the React program, though a more limited set of simulations was also carried out in which the $\mathrm{pH}$ was set at 6.0, 6.8, 7.1 and 7.4. This was performed to allow the investigation of the effect of $\mathrm{pH}$ on bioaccessibility at the physiological $\mathrm{pHs}$ for particulate-lung fluid interactions, given the possibility of local changes in $\mathrm{pH}$ as a result of particle deposition.

\subsubsection{Aqueous Chemistry Simulation Using OLI Studio 9.5}

For modelling using OLI, a similar procedure was carried out to that specified for GWB 14 in terms of defining the initial aqueous model, though because of the difference in inputting chemical substances in OLI 9.5 compared to GWB 14, hydroxides of the metals were used as inputs. All of the species listed in Section 2.2.1 were included in the model, with the addition of $\mathrm{Ni}(\mathrm{OH})_{2}$ and $\mathrm{Cd}(\mathrm{OH})_{2}$ and $\mathrm{Sb}(\mathrm{OH})_{5}$, which were not available in the GWB thermochemical databases, but were in OLI Studio. To allow direct comparison to the GWB results, the $\mathrm{pH}$ was fixed at the value calculated from the GWB runs for the specified $\mathrm{S} / \mathrm{L}$ ratio. To achieve the desired $\mathrm{pH}, \mathrm{HCl}$ was specified as the titrant. The default aqueous chemistry thermochemical database for OLI 9.5 was used, and was run with and without citrate and glycine, to allow comparison with the MINTEQ database used in GWB 14.

\subsection{Calculation of Modelled Bioccessibilty}

Outputs from both GWB 14 and OLI Studio 9.5 give aqueous and whole-system elemental totals, allowing a straightforward calculation of the \% of the aqueous species present in solution compared to the theoretical maximum. For the extractability work carried out in the present paper, comparisons were made with $\mathrm{As}, \mathrm{Cu}, \mathrm{Mn}, \mathrm{Pb}$, and $\mathrm{Zn}$. For comparisons with the work of Caboche et al. [8], only $\mathrm{Zn}$ and $\mathrm{Pb}$ were used, as these were the only two PTEs for which extractability data were determined over a range of S/L ratios. In addition to the elemental totals in the solid and liquid phases, GWB 14 and OLI 9.5 generate a full aqueous- and solid-phase speciation of the elements.

\subsection{Evaluation of Model Performance}

To obtain a more objective consideration of the performance of the models, two statistical tests were used: fractional bias of the mean $\left(F B_{\text {mean }}\right)$, Equation (1), which gives an indication of the extent of systematic bias, and normalised mean square error (NMSE), Equation (2), which quantifies the random bias. Both of these tests are used to evaluate environmental models in the literature [36,37]. In Equations (1) and (2), $C_{o b s}$ and $C_{\text {pred }}$ are the observed and predicted concentrations, respectively. For both $F B_{\text {mean }}$ and NMSE, a perfect model would give values of zero. However, in evaluative terms, $F B_{\text {mean }}$ (absolute) values of $<0.3$ (i.e., less than $30 \%$ deviation from the actual mean) and NMSE values $<1.5$ are generally considered acceptable [37].

$$
\begin{gathered}
F B_{\text {mean }}=2\left(\frac{\bar{C}_{o b s}-\bar{C}_{\text {pred }}}{{\overline{\bar{C}_{o b s}}}_{\bar{C}_{\text {pred }}}}\right) \\
\text { NMSE }=\frac{\overline{\left(C_{o b s}-C_{\text {pred }}\right)^{2}}}{{\overline{C_{o b s}}}_{\text {pred }}}
\end{gathered}
$$




\section{Results and Discussion}

\subsection{Bioaccessibility of $\mathrm{As}, \mathrm{Cu}, \mathrm{Mn}, \mathrm{Pb}$ and $\mathrm{Zn}$ from NIST 2710a in Simulated Lung Fluid}

Table 1 lists the certified values for the PTEs used in this study, together with the determined total concentrations for NIST 2710a. The percentage recoveries obtained for 2710a are: $\mathrm{As}, 94 \% ; \mathrm{Cu}, 100 \% ; \mathrm{Mn}, 81 \% ; \mathrm{Pb}, 97 \% ; \mathrm{Zn}, 98 \%$.

Table 1. Certified values for the SRMs used in the aqueous chemistry modelling (NIST 1648 and BCR 038 were used in comparisons with the results of Caboche et al. [8]). The values in parentheses for NIST 2710a are the determined concentrations (one extraction only, due to limited availability of the SRM).

\begin{tabular}{cccc}
\hline \multirow{2}{*}{ Element } & \multicolumn{3}{c}{ SRM Certified Values/mg kg $\mathbf{~}^{-\mathbf{1}}$} \\
& $\begin{array}{c}\text { NIST 2710a (Montana } \\
\text { Soil, This Work) }\end{array}$ & $\begin{array}{c}\text { NIST 1648a } \\
\text { (Urban Atmospheric PM [8]) }\end{array}$ & $\begin{array}{c}\text { BCR 038 } \\
\text { (Fly Ash [8]) }\end{array}$ \\
\hline $\mathrm{As}$ & $1540 \pm 100(1450)$ & $115.5 \pm 3.9$ & $48 \pm 2.3$ \\
$\mathrm{Cu}$ & $3420 \pm 50(3430)$ & $610 \pm 70$ & $176 \pm 9$ \\
$\mathrm{Mn}$ & $2140 \pm 60(1740)$ & $790 \pm 44$ & $479 \pm 16$ \\
$\mathrm{~Pb}$ & $5520 \pm 30(5360)$ & $6550 \pm 330$ & $262 \pm 11$ \\
$\mathrm{Zn}$ & $4180 \pm 150(4100)$ & $4800 \pm 270$ & $581 \pm 29$ \\
\hline
\end{tabular}

Table 2 details the measured bioaccessibility of $\mathrm{As}, \mathrm{Cu}, \mathrm{Mn}, \mathrm{Pb}$ and $\mathrm{Zn}$ in the SLF, both in the presence and absence of DPPC surfactant. In both cases, the lowest bioaccessibilities are associated with the highest $\mathrm{S} / \mathrm{L}$ ratios, i.e., the most concentrated solutions, as has previously been observed $[8,14,17]$; this is likely to be due to species becoming saturated at these higher concentrations and also the possibility of a reduced surface area for the exposed particulate [8]. The difference in \% bioaccessibility at an S/L ratio of $1 / 30$ compared to the more dilute solutions is more significant for our study compared to other studies, for example that by Caboche et al. [8], though this may simply reflect the different SRMs used. Where \% bioaccessibility data are present for NIST 2710a from other studies [14], the S/L ratios used are not equivalent, and so a direct comparison cannot be made. Nevertheless, Pelfrêne et al. did observe a significant $\mathrm{S} / \mathrm{L}$ ratio-dependent extraction profile for many metals between the $\mathrm{S} / \mathrm{L}$ ratios $1 / 1000$ and $1 / 10,000$, most notably for $\mathrm{Pb}(2.2-11.8 \%), \mathrm{Zn}(13.2-25.9 \%)$ and $\mathrm{Mn}(31.8-40.9 \%)$, though $\mathrm{Cu}$ ranged in the opposite direction $(49.4-36.9 \%)$ [14].

Table 2. Bioaccessible concentration $\left(\mathrm{mg} \mathrm{kg}^{-1}\right)$ of various PTEs from NIST 2710a at different ratios of particulate to SLF (S/L ratio). Values in parentheses are the corresponding \% bioaccessibilities, based on the certified values listed in Table 1.

\begin{tabular}{|c|c|c|c|c|c|}
\hline \multirow[b]{2}{*}{ S/L Ratio/g mL $\mathbf{~}^{-1}$} & \multicolumn{5}{|c|}{ Bioaccessible Concentrations/mg kg ${ }^{-1}$ (with \% Bioaccessibility in Parentheses) } \\
\hline & As & $\mathrm{Cu}$ & $\mathrm{Pb}$ & Mn & Zn \\
\hline \multicolumn{6}{|l|}{ Without DPPC } \\
\hline $1 / 4000$ & $\begin{array}{c}580 \pm 49.8 \\
(37.7 \pm 3.2)\end{array}$ & $\begin{array}{l}1700 \pm 28.9 \\
(49.7 \pm 0.8)\end{array}$ & $\begin{array}{l}531 \pm 25.4 \\
(9.6 \pm 0.5)\end{array}$ & $\begin{array}{c}648 \pm 49.0 \\
(30.3 \pm 2.3)\end{array}$ & $\begin{array}{c}585 \pm 32.9 \\
(14 \pm 0.8)\end{array}$ \\
\hline $1 / 2000$ & $\begin{array}{c}495 \pm 11.2 \\
(32.1 \pm 0.7)\end{array}$ & $\begin{array}{l}2020 \pm 27.2 \\
(59.1 \pm 0.8)\end{array}$ & $\begin{array}{l}228 \pm 20.5 \\
(4.1 \pm 0.4)\end{array}$ & $\begin{array}{c}812 \pm 140 \\
(37.9 \pm 6.5)\end{array}$ & $\begin{array}{l}511 \pm 14.8 \\
(12.2 \pm 0.4)\end{array}$ \\
\hline $1 / 500$ & $\begin{array}{c}328 \pm 17.1 \\
(21.3 \pm 1.1)\end{array}$ & $\begin{array}{l}1770 \pm 75.8 \\
(51.8 \pm 2.2)\end{array}$ & $\begin{array}{l}114 \pm 11.8 \\
(2.1 \pm 0.2)\end{array}$ & $\begin{array}{c}602 \pm 29.9 \\
(28.1 \pm 1.4)\end{array}$ & $\begin{array}{l}253 \pm 24.6 \\
(6.1 \pm 0.6)\end{array}$ \\
\hline $1 / 30$ & $\begin{array}{c}20.4 \pm 0.61 \\
(1.3 \pm 0.0)\end{array}$ & $\begin{array}{c}1060 \pm 21.7 \\
(31 \pm 0.6)\end{array}$ & $\begin{array}{c}10.1 \pm 0.43 \\
(0.2 \pm 0.0)\end{array}$ & $\begin{array}{c}367 \pm 6.6 \\
(17.1 \pm 0.3)\end{array}$ & $\begin{array}{c}78.5 \pm 2.43 \\
(1.9 \pm 0.1)\end{array}$ \\
\hline \multicolumn{6}{|l|}{ With DPPC } \\
\hline $1 / 4000$ & $\begin{array}{c}597 \pm 46.7 \\
(38.8 \pm 3)\end{array}$ & $\begin{array}{c}1950 \pm 114 \\
(57 \pm 3.3)\end{array}$ & $\begin{array}{l}324 \pm 19.7 \\
(5.9 \pm 0.4)\end{array}$ & $\begin{array}{c}802 \pm 53.3 \\
(37.5 \pm 2.5)\end{array}$ & $\begin{array}{c}635 \pm 23.5 \\
(15.2 \pm 0.6)\end{array}$ \\
\hline $1 / 2000$ & $\begin{array}{c}484 \pm 21.8 \\
(31.4 \pm 1.4)\end{array}$ & $\begin{array}{l}1920 \pm 81.9 \\
(56.1 \pm 2.4)\end{array}$ & $\begin{array}{l}217 \pm 5.36 \\
(3.9 \pm 0.1)\end{array}$ & $\begin{array}{c}748 \pm 74.9 \\
(35 \pm 3.5)\end{array}$ & $\begin{array}{c}525 \pm 38.3 \\
(12.6 \pm 0.9)\end{array}$ \\
\hline $1 / 500$ & $\begin{array}{l}336 \pm 6.19 \\
(21.8 \pm 0.4)\end{array}$ & $\begin{array}{c}1760 \pm 69.2 \\
(51.5 \pm 2)\end{array}$ & $\begin{array}{c}57.3 \pm 3.79 \\
(1.0 \pm 0.1)\end{array}$ & $\begin{array}{c}602 \pm 24.6 \\
(28.1 \pm 1.1)\end{array}$ & $\begin{array}{l}254 \pm 23.3 \\
(6.1 \pm 0.6)\end{array}$ \\
\hline $1 / 30$ & $\begin{array}{c}17.9 \pm 1.3 \\
(1.2 \pm 0.1)\end{array}$ & $\begin{array}{l}1090 \pm 14.4 \\
(31.9 \pm 0.4)\end{array}$ & $\begin{array}{c}9.58 \pm 0.26 \\
(0.2 \pm 0.0)\end{array}$ & $\begin{array}{c}383 \pm 7.70 \\
(17.9 \pm 0.4)\end{array}$ & $\begin{array}{c}82.8 \pm 3.53 \\
(2.0 \pm 0.1)\end{array}$ \\
\hline
\end{tabular}


We found that the general order of extractability for NIST 2710a (from highest to lowest) is $\mathrm{Cu}>\mathrm{Mn} \sim \mathrm{As}>\mathrm{Zn}>\mathrm{Pb}$. Table 3 shows that our results are in very good agreement with previous inhalation bioaccessibility studies on this SRM [14,15], particularly for the study of Pelfrêne et al., where two variants of Gamble's solution were used, with 'Modified Gambles' referring to the addition of DPPC [14]. The study of Meza-Figueroa et al. [15] reported lower extractabilities for all elements compared to both our study and that of Pelfrêne et al. [14]. This might be explained by the different SLF compositions used, particularly the absence of glycine in the Meza-Figueroa et al. study [15]. It has previously been reported that glycine can form complexes with several different metals ions, thus aiding extractability [15].

Table 3. Comparison of \% bioaccessibility: current compared with similar studies in the literature (all at an S/L ratio of 1/2000, except for Meza-Figueroa et al. [15], where the ratio was 1/1000).

\begin{tabular}{ccccc}
\hline PTE & This Work & $\begin{array}{c}\text { Pelfrêne et al. [14] } \\
\text { (Gamble) }\end{array}$ & $\begin{array}{c}\text { Pelfrêne et al. [14] (Modified } \\
\text { Gamble-Containing DPPC) }\end{array}$ & Meza-Figueroa et al. [15] \\
\hline $\mathrm{As}$ & 32.1 & - & & - \\
$\mathrm{Cu}$ & 59.1 & 52.1 & 47.4 & 39 \\
$\mathrm{~Pb}$ & 4.1 & 3.7 & 3.8 & 0.1 \\
$\mathrm{Mn}$ & 37.9 & 37.3 & 36.6 & 22.6 \\
$\mathrm{Zn}$ & 12.2 & 18.6 & 18.6 & 0.6 \\
\hline
\end{tabular}

Our results show that the presence of DPPC does not significantly increase bioaccessibility. The Related-Samples Wilcoxon Signed Rank Test, carried out on results for extractions carried out in the presence and absence of DPPC, gave $p$-values of $0.778,0.715$, $0.715,0.068,0.593$ and 0.068 for all data $(\mathrm{n}=20), \mathrm{As}(\mathrm{n}=4), \mathrm{Cu}(\mathrm{n}=4), \mathrm{Pb}(\mathrm{n}=4), \mathrm{Mn}(\mathrm{n}=4)$ and $\mathrm{Zn}(\mathrm{n}=4)$, respectively, at the $95 \%$ probability level. For comparisons of all metal data on the basis of the $\mathrm{S} / \mathrm{L}$ ratio, $p$-values of $0.345,0.223,0.465$ and 0.225 were obtained for $S / L$ ratios of $1 / 4000,1 / 2,000,1 / 500$ and $1 / 30$, respectively (all $n=5)$. This result largely reflects the conclusions of Pelfrêne et al. [14], who compared SLF extractabilities in Gambles solution, with and without DPPC present. For the five PTEs investigated in our study, Pelfrêne et al. [14] previously found no statistical difference in \% bioaccessibility for $\mathrm{Pb}$ or $\mathrm{Mn}$ in any of the three SRMs. Small, but statistically significant differences were observed with $\mathrm{Cu}$ (lower when DPPC present) and Zn (higher when DPPC present) for NIST 2710a. Nevertheless, Li et al. [38] found that the Pb bioaccessibility range for $\mathrm{PM}_{2.5}$ sampled in Nanjing reduced from $23-43 \%$ to $5.6-18 \%$ if DPCC was omitted from Gamble's solution. The addition of DPCC is thought to aid wettability of the particles and prevent aggregation $[5,8,39]$.

\subsection{Comparison of Modelled and Experimentally Determined Bioaccessibilities}

For our modelling predictions using the five thermochemical databases, we have made comparisons with both our own experimentally determined bioaccessibilities for NIST 2710a (Montana soil), Figure 1, and with bioaccessibilities reported in the literature for NIST 1648a (urban atmospheric PM), and BCR 038 (fly ash), Figure 2. For two of the databases, MINTEQ and OLI, the inclusion of glycine and citrate as species allowed a comparison to be made of bioaccessibility in the presence and absence of these metal ion chelators, that are integral components of the Gamble's extraction solution [5,8]. In addition to the extractability profiles presented in Figures 1 and 2, we have summarised in Table 4 the most significant aqueous species that are predicted to be present for NIST 2710a at an $\mathrm{S} / \mathrm{L}$ ratio of $1 / 500 \mathrm{~g} \mathrm{~mL}^{-1}$ for each of the thermochemical databases. The top five most abundant species (if present) are presented in order, though the first two or three species will generally account for $\sim 95 \%$ or more of the aqueous phase for each of the species. A detailed analysis of the concentrations of the species has not been presented, as this will vary according to $\mathrm{pH}$, the $\mathrm{S} / \mathrm{L}$ ratio and elemental concentration for the SRMs. 
Nevertheless, the list of species gives a useful comparison of the components of the SLF that solubilise the PTEs under investigation. Table 4 also shows the likely precipitating species.
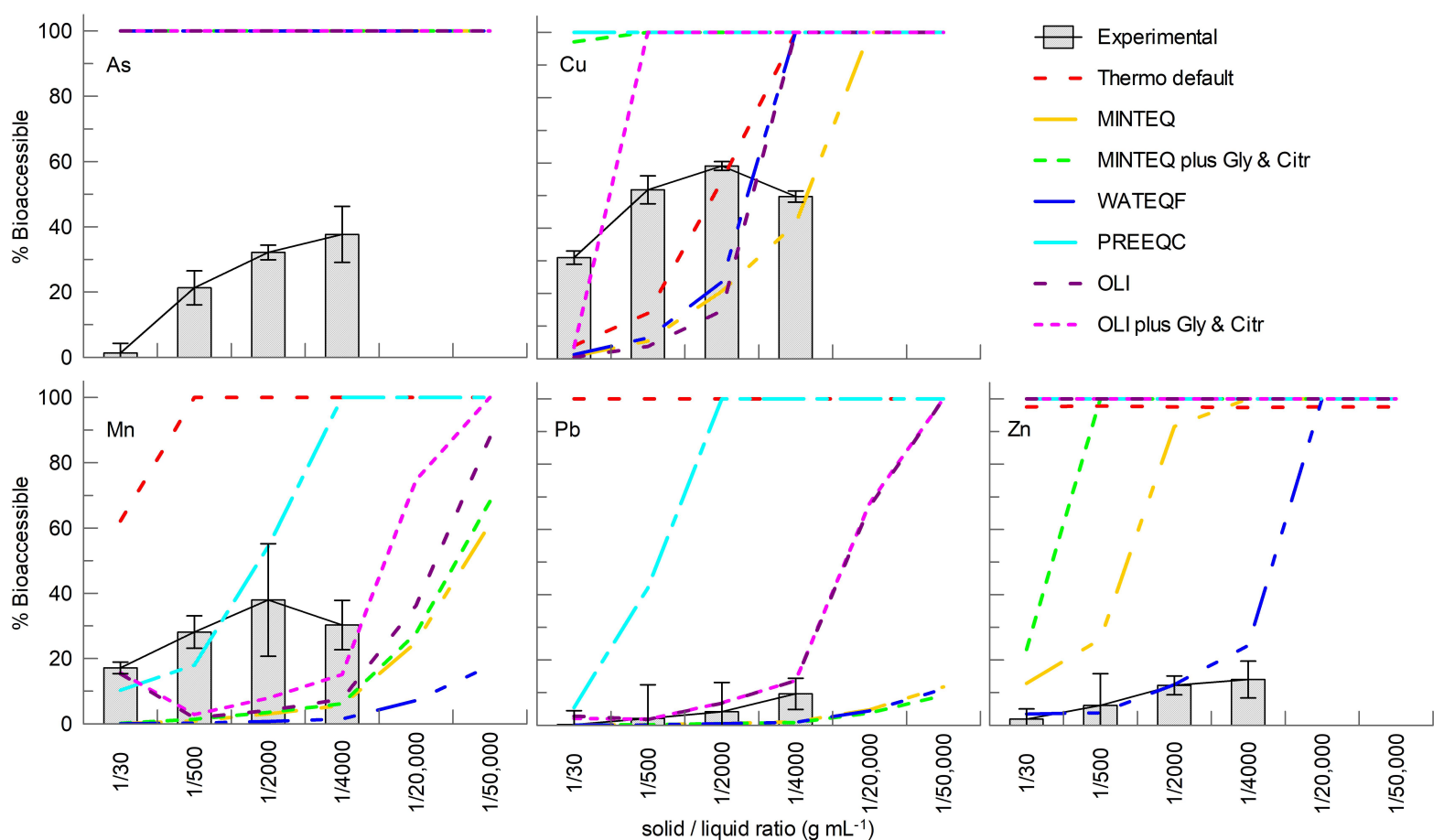

Figure 1. Comparison of observed against modelled PTE \% bioaccessibilities for NIST 2710a. Modelled results are for the thermochemical databases described in the legend. No experimental bioaccessibilities were determined for S/L ratios of $1 / 20,000$ or $1 / 50,000$, though modelling was carried out at these $\mathrm{S} / \mathrm{L}$ ratios so as to be consistent with those used by Caboche et al. [8]. Note that for As, all the curves are overlaid at $100 \%$.

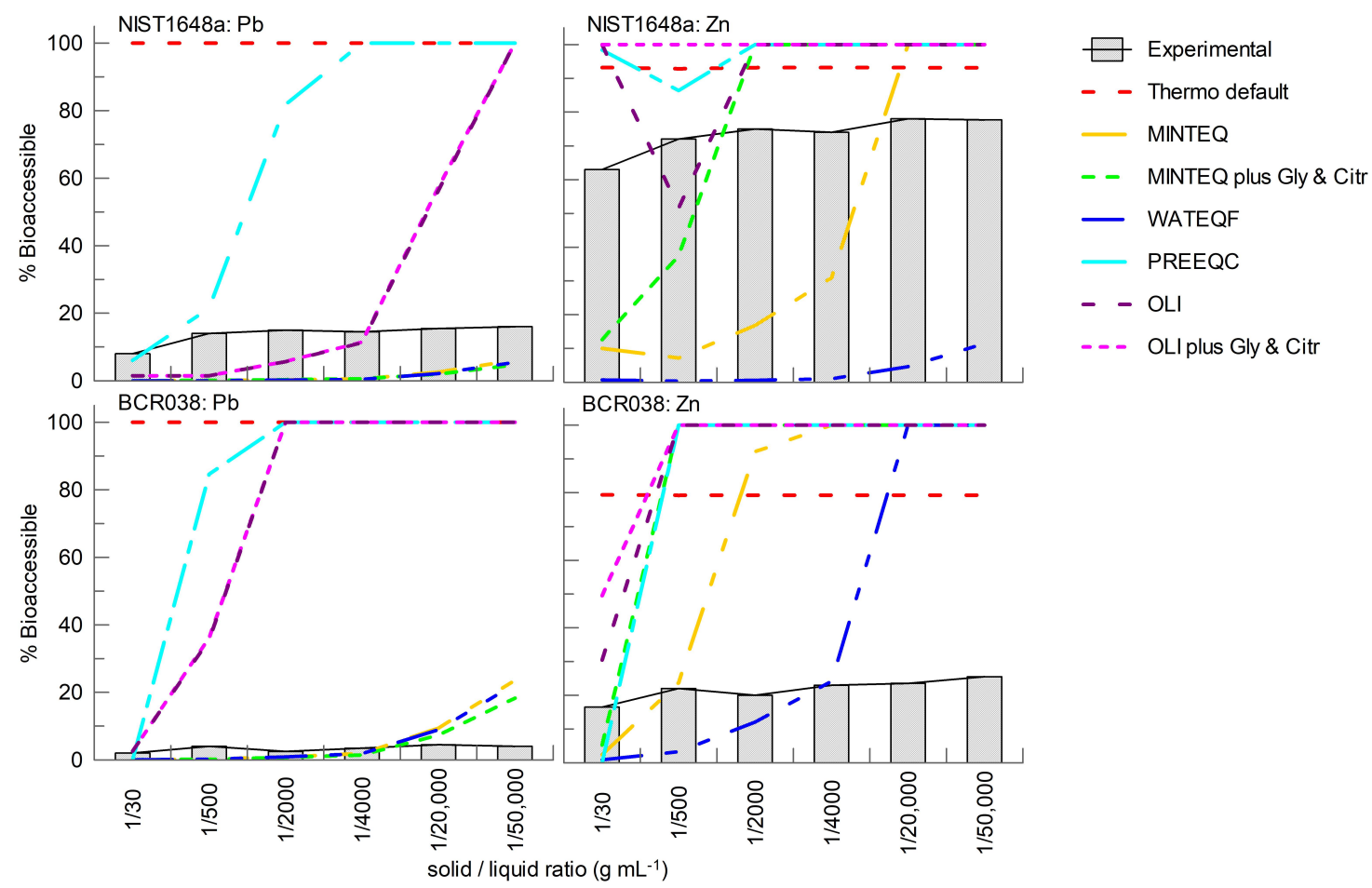

Figure 2. Comparison of observed against modelled PTE\% bioaccessibilities for NIST 1648a and BCR 038 results from Caboche et al. [8]. Modelled results are for the thermochemical databases described in the legend. 
Table 4. Top five most abundant aqueous species determined at equilibrium for different thermochemical databases at an $\mathrm{S} / \mathrm{L}$ ratio of $1 / 500 \mathrm{~g} \mathrm{~mL}^{-1}$. The main solid-phase species are also shown. The stated $\mathrm{pH}$ is the calculated equilibrium value.

\begin{tabular}{|c|c|c|c|c|c|c|}
\hline Database & Phase & As & $\mathrm{Cu}$ & $\mathbf{P b}$ & Mn & $\mathrm{Zn}$ \\
\hline \multirow[t]{2}{*}{$\begin{array}{l}\text { GWB default } \\
\quad(\mathrm{pH} 6.40)\end{array}$} & $\mathrm{Aq}$ & \multirow[t]{2}{*}{$\begin{array}{l}\mathrm{HAsO}_{4}^{2-} \\
\mathrm{H}_{2} \mathrm{AsO}_{4}^{-}\end{array}$} & $\begin{array}{c}\mathrm{Cu}^{2+} \\
\mathrm{CuOH}^{+} \\
\mathrm{CuCl}^{+}\end{array}$ & $\mathrm{PbCO}_{3}$ & \multirow[t]{2}{*}{$\begin{array}{c}\mathrm{Mn}^{2+} \\
\mathrm{MnHCO}_{3}^{+} \\
\mathrm{MnSO}_{4}\end{array}$} & $\begin{array}{c}\mathrm{Zn}^{2+} \\
\mathrm{ZnCl}^{+} \\
\mathrm{ZnCl}_{2} \\
\mathrm{ZnSO}_{4}\end{array}$ \\
\hline & Solid & & $\mathrm{Cu}_{2} \mathrm{CO}_{3}(\mathrm{OH})_{2}$ & $\begin{array}{c}\mathrm{PbCO}_{3} \\
\mathrm{PbHCO}_{3}^{+}\end{array}$ & & $\mathrm{ZnCr}_{2} \mathrm{O}_{4}$ \\
\hline \multirow[t]{2}{*}{$\begin{array}{l}\text { MINTEQ } \\
(\mathrm{pH} 7.057)\end{array}$} & $\mathrm{Aq}$ & \multirow[t]{2}{*}{$\begin{array}{c}\mathrm{HAsO}_{4}{ }^{2-} \\
\mathrm{H}_{2} \mathrm{AsO}_{4}{ }^{-} \\
\mathrm{H}_{3} \mathrm{AsO}_{3} \\
\mathrm{H}_{2} \mathrm{AsO}_{3}{ }^{-}\end{array}$} & $\begin{array}{c}\mathrm{CuCO}_{3}(\mathrm{aq}) \\
\mathrm{Cu}\left(\mathrm{CO}_{3}\right)_{2}^{2-} \\
\mathrm{CuHCO}_{3}{ }^{+} \\
\mathrm{Cu}^{2+}\end{array}$ & $\begin{array}{c}\mathrm{PbCO}_{3} \\
\mathrm{PbHCO}_{3}^{+}\end{array}$ & $\begin{array}{c}\mathrm{Mn}^{2+} \\
\mathrm{MnCO}_{3}(\mathrm{aq}) \\
\mathrm{MnHCO}_{3}^{+}\end{array}$ & \multirow{2}{*}{$\begin{array}{c}\mathrm{Zn}^{2+} \\
\mathrm{ZnHCO}_{3}^{+} \\
\mathrm{ZnCO}_{3}(\mathrm{aq}) \\
\mathrm{ZnCl}^{+} \\
\mathrm{ZnCl}_{2}(\mathrm{aq}) \\
\mathrm{Zn}\left(\mathrm{CO}_{3}\right)\end{array}$} \\
\hline & Solid & & $\mathrm{Cu}_{2} \mathrm{CO}_{3}(\mathrm{OH})_{2}$ & $\mathrm{~Pb}_{3}\left(\mathrm{PO}_{4}\right)_{2}$ & $\mathrm{MnHPO}_{4}$ & \\
\hline \multirow[t]{2}{*}{$\begin{array}{c}\text { MINTEQ + citr. } \\
\text { and gly. } \\
\text { (pH 7.11) }\end{array}$} & $\mathrm{Aq}$ & \multirow[t]{2}{*}{$\begin{array}{c}\mathrm{HAsO}_{4}{ }^{2-} \\
\mathrm{H}_{2} \mathrm{AsO}_{4}^{-} \\
\mathrm{H}_{3} \mathrm{AsO}_{3} \\
\mathrm{H}_{2} \mathrm{AsO}_{3}{ }^{-}\end{array}$} & $\begin{array}{c}\mathrm{Cu} \text {-(glycine })_{2} \\
\text { Cu-glycine } \\
\mathrm{Cu}^{+} \text {-citrate } \\
\mathrm{CuCO}_{3}(\mathrm{aq})\end{array}$ & $\begin{array}{c}\mathrm{PbCO}_{3} \\
\mathrm{PbHCO}_{3}^{+}\end{array}$ & $\begin{array}{c}\text { Mn-citrate } \\
\mathrm{Mn}^{2+} \\
\mathrm{MnCO}_{3}(\mathrm{aq}) \\
\mathrm{MnHCO}_{3}{ }^{+}\end{array}$ & \multirow[t]{2}{*}{$\begin{array}{c}\mathrm{Zn} \text {-citrate } \\
\text { Zn-(citrate) })_{2}{ }^{3-} \\
\mathrm{Zn} \text {-glycine } \\
\mathrm{Zn}^{2+} \\
\mathrm{ZnHCO}_{3}^{+}\end{array}$} \\
\hline & Solid & & $\mathrm{Cu}_{2} \mathrm{CO}_{3}(\mathrm{OH})_{2}$ & $\mathrm{~Pb}_{3}\left(\mathrm{PO}_{4}\right)_{2}$ & $\mathrm{MnHPO}_{4}$ & \\
\hline \multirow[t]{2}{*}{$\begin{array}{l}\text { WATEQ4F } \\
(\mathrm{pH} 7.05)\end{array}$} & $\mathrm{Aq}$ & \multirow[t]{2}{*}{$\begin{array}{l}\mathrm{HAsO}_{4}^{2-} \\
\mathrm{H}_{2} \mathrm{AsO}_{4}^{-}\end{array}$} & $\begin{array}{c}\mathrm{CuCO}_{3}(\mathrm{aq}) \\
\mathrm{CuHCO}_{3}{ }^{+} \\
\mathrm{Cu}\left(\mathrm{CO}_{3}\right)_{2}{ }^{2-} \\
\mathrm{Cu}(\mathrm{OH})_{2}(\mathrm{aq}) \\
\mathrm{Cu}^{2+}\end{array}$ & $\begin{array}{l}\text { No significant } \\
\text { aqueous species }\end{array}$ & $\underset{\mathrm{Mn}^{2+}}{\mathrm{MnHCO}_{3}+}$ & $\begin{array}{c}\mathrm{ZnHCO}_{3}{ }^{+} \\
\mathrm{Zn}\left(\mathrm{CO}_{3}\right)^{2-} \\
\mathrm{ZnCO}_{3} \\
\mathrm{Zn}^{2+} \\
\mathrm{ZnCl}^{+}\end{array}$ \\
\hline & Solid & & $\mathrm{Cu}_{2} \mathrm{CO}_{3}(\mathrm{OH})_{2}$ & $\mathrm{~Pb}_{5}\left(\mathrm{PO}_{4}\right)_{3} \mathrm{Cl}$ & $\mathrm{MnHPO}_{4}$ & $\mathrm{ZnSiO}_{3}$ \\
\hline $\begin{array}{l}\text { PHREEQC } \\
(\mathrm{pH} 6.96)\end{array}$ & Solid & - & $\begin{array}{c}\mathrm{Cu}^{2+} \\
\mathrm{Cu}(\mathrm{OH})_{2} \\
\mathrm{CuOH}^{+} \\
\mathrm{CuSO}_{4}\end{array}$ & $\begin{array}{c}\mathrm{PbCO}_{3} \\
\mathrm{PbHCO}_{3}^{+} \\
\mathrm{Pb}\left(\mathrm{CO}_{3}\right)_{2}^{2-} \\
\mathrm{PbCl}^{+} \\
\mathrm{Pb}^{2+} \\
\mathrm{Pb}(\mathrm{OH})_{2}\end{array}$ & $\begin{array}{c}\mathrm{MnHCO}_{3}^{+} \\
\mathrm{Mn}^{2+} \\
\mathrm{MnCO}_{3} \\
\mathrm{MnCl}^{+} \\
\mathrm{MnHCO}_{3}^{+} \\
\mathrm{MnCO}_{3}\end{array}$ & $\begin{array}{c}\mathrm{ZnHCO}_{3}^{+} \\
\mathrm{Zn}\left(\mathrm{CO}_{3}\right)_{2}^{2-} \\
\mathrm{ZnCO}_{3} \\
\mathrm{Zn}^{2+} \\
\mathrm{ZnCl}^{+}\end{array}$ \\
\hline $\begin{array}{c}\text { OLI + citr. and } \\
\text { gly. } \\
\text { (pH 7.00) }\end{array}$ & Solid & $\mathrm{HAsO}_{4}{ }^{2-}$ & $\begin{array}{c}\mathrm{Cu}-(\text { glycine })_{2} \\
\mathrm{Cu} \text {-glycine } \\
\mathrm{Cu}^{+} \text {-itrate } \\
\mathrm{CuCO}_{3} \\
\mathrm{CuNH}_{3}{ }^{2+} \\
\mathrm{Cu}_{2}(\mathrm{OH})_{2} \mathrm{CO}_{3}\end{array}$ & $\begin{array}{c}\mathrm{PbCO}_{3} \\
\mathrm{PbOH}^{+} \\
\mathrm{Pb}\left(\mathrm{CO}_{3}\right)_{2}^{2-} \\
\mathrm{PbCl}^{+} \\
\mathrm{Pb}^{2+} \\
\mathrm{PbCO}_{3} \\
\end{array}$ & $\begin{array}{c}\text { Mn-citrate }^{-} \\
\mathrm{Mn}^{2+} \\
\mathrm{MnCl}^{+} \\
\mathrm{MnSO}_{4} \\
\mathrm{Mn} \text {-glycine }^{+} \\
\mathrm{MnCO}_{3} \\
\end{array}$ & $\begin{array}{c}\text { Zn-citrate } \\
\mathrm{Zn}^{2+} \\
\mathrm{Zn} \text {-glycine } \\
\mathrm{ZnHCO}_{3}^{+} \\
\mathrm{ZnCl}^{+}\end{array}$ \\
\hline $\begin{array}{c}\text { OLI } \\
(\mathrm{pH} 7.00)\end{array}$ & Solid & $\mathrm{HAsO}_{4}{ }^{2-}$ & $\begin{array}{c}\mathrm{CuCO}_{3} \\
\mathrm{CuNH}_{3}{ }^{2+} \\
\mathrm{Cu}\left(\mathrm{CO}_{3}\right)_{2}{ }^{2-} \\
\mathrm{Cu}^{2+} \\
\mathrm{CuCl}^{+} \\
\mathrm{Cu}_{3}\left(\mathrm{PO}_{4}\right)_{2} \cdot 2 \mathrm{H}_{2} \mathrm{O}\end{array}$ & $\begin{array}{c}\mathrm{PbCO}_{3} \\
\mathrm{PbOH}^{+} \\
\mathrm{Pb}\left(\mathrm{CO}_{3}\right)_{2}^{2-} \\
\mathrm{PbCl}^{+} \\
\mathrm{Pb}^{2+} \\
\mathrm{PbCO}_{3}\end{array}$ & $\begin{array}{c}\mathrm{Mn}^{2+} \\
\mathrm{MnCl}^{+} \\
\mathrm{MnSO}_{4} \\
\mathrm{MnCO}_{3}\end{array}$ & $\begin{array}{c}\mathrm{Zn}^{2+} \\
\mathrm{ZnHCO}_{3}^{+} \\
\mathrm{ZnCl}^{+} \\
\mathrm{ZnOH}^{+} \\
\mathrm{ZnCl}_{2}\end{array}$ \\
\hline
\end{tabular}

\subsubsection{Comparison of Modelled and Predicted Bioaccessibilities for NIST 2710a}

From Figure 1, we can see that the bioaccessibilities predicted by the different thermochemical databases vary considerably and have a mixed performance with respect to correlation with experimentally determined values. Nevertheless, the experimentally determined trend of increasing bioaccessibility with lower S/L ratios is replicated by the modelling, though different models seem to work better for specific PTEs. Thus, OLI Studio seems to describe $\mathrm{Pb}$ bioaccessibility well, whereas WATQ4F would appear to work better for $\mathrm{Zn}$, and PHREEQC for Mn. Of the literature explanations for the relationship between the $S / L$ ratio and bioaccessibility, i.e., saturation of chemical species at the highest $S / L$ 
ratios and reduced surface area for extraction [8], the modelling can only account for the former, though this seems to be a dominant process.

$F B_{\text {mean }}$ and NMSE were applied to predicted vs. actual bioaccessibility data for the individual metals. The results of the analysis are shown in Table 5. The values obtained for both $F B_{\text {mean }}$ and NMSE show that the models generally perform outside the acceptability criteria, though there are exceptions, such as the performance of the GWB Thermo database for $\mathrm{Cu}$ and WATQ4F for $\mathrm{Zn}$, where both $F B_{\text {mean }}$ and NMSE have values within the performance criteria. OLI also appears to give a reasonable performance for $\mathrm{Pb}$ and Zn (NMSE conforms to the performance criteria, both with and without glycine/citrate, though the latter performs better).

Table 5. Performance metrics for bioaccessibility modelling for NIST 2710. Values in bold indicate 'acceptable' performance [37].

\begin{tabular}{|c|c|c|c|c|c|c|c|}
\hline $\begin{array}{l}\text { Statistical Measure } \\
\text { and Metal }\end{array}$ & $\begin{array}{c}\text { GWB } \\
\text { Thermo }\end{array}$ & MINTEQ & $\begin{array}{l}\text { MINTEQ + } \\
\text { gly. and citr. }\end{array}$ & PHREEQC & WAT4QF & $\begin{array}{l}\text { OLI + gly. } \\
\text { and citr. }\end{array}$ & OLI \\
\hline \multicolumn{8}{|l|}{$F B_{\text {mean }}$} \\
\hline As & -1.25 & -1.25 & -1.25 & - & -1.25 & -1.25 & -1.25 \\
\hline $\mathrm{Cu}$ & 0.11 & 0.95 & -0.70 & -0.70 & 0.37 & -0.45 & 0.47 \\
\hline $\mathrm{Pb}$ & -1.85 & 1.62 & 1.68 & -1.76 & 1.67 & -0.71 & -0.44 \\
\hline $\mathrm{Mn}$ & -1.05 & 1.69 & 1.64 & -0.47 & 1.92 & 0.93 & 1.19 \\
\hline $\mathrm{Zn}$ & -1.68 & -1.48 & -1.62 & -1.69 & -0.25 & -1.69 & -1.69 \\
\hline \multicolumn{8}{|l|}{ NMSE } \\
\hline As & 2.64 & 2.64 & 2.64 & - & 2.64 & 2.64 & 2.64 \\
\hline $\mathrm{Cu}$ & 0.52 & 1.29 & 0.57 & 0.59 & 1.00 & 0.45 & 1.28 \\
\hline $\mathrm{Pb}$ & 23.07 & 7.39 & 9.80 & 12.98 & 8.96 & 0.58 & 0.18 \\
\hline $\mathrm{Mn}$ & 1.49 & 9.22 & 7.75 & 0.91 & 43.19 & 1.62 & 3.40 \\
\hline $\mathrm{Zn}$ & 9.55 & 5.26 & 7.45 & 9.83 & 0.22 & 9.83 & 9.83 \\
\hline
\end{tabular}

Perhaps the most important observation from the results of modelling studies shown in Figure 1 is that many of the models predict very high bioaccessibilities at the most dilute $\mathrm{S} / \mathrm{L}$ ratios for all PTEs, with several predicting high bioaccessibilities at medium S/L ratios. Thus, for As, all models predict $100 \%$ bioaccessibility across all S/L ratios. For $\mathrm{Cu}$ and $\mathrm{Zn}$ all models predict $100 \%$ bioaccessibility at the lowest $\mathrm{S} / \mathrm{L}$ ratio. For $\mathrm{Mn}$, all models except WATEQ4F; and for Pb, all models except WATEQ4F and MINTEQ predict high bioaccessibilities at low $\mathrm{S} / \mathrm{L}$ ratios.

From Table 4, we can see that for modelling runs conducted in the absence of glycine and citrate, the main solubilising SLF components are carbonate and chloride across all species apart from As. Free ions are also predicted to play a role in the solubility of $\mathrm{Cu}, \mathrm{Mn}$ and $\mathrm{Zn}$, and hydroxide complexes are, additionally, predicted to aid the solubility of $\mathrm{Cu}$. In simulated leaching experiments of fly ash components into water, Ettler et al. found that chloro complexes tend to dominate the solubility of all metals studied ( $\mathrm{Pb}, \mathrm{Cu}, \mathrm{Cd}$ and $\mathrm{Zn}$ ), with free ions also significant for $\mathrm{Cu}$ and $\mathrm{Zn}[19,22]$. Additional contributions to aqueous solubility were provided by a number of minor soluble sulphate and carbonate complexes, though the pHs were lower than in our study $[19,22]$. From the species data in Table 4 , the metals will precipitate out of solution as carbonates, and phosphates. Arsenic solubility appears unaffected by the SLF components, but are instead dependent on the presence of the $\mathrm{HAsO}_{4}{ }^{2-}$ ion and its conjugate acid, $\mathrm{H}_{2} \mathrm{AsO}_{4}{ }^{-}$(the $\mathrm{pKa}$ of the latter, arsenic acid, is 6.97 [40], so a similar pH to the SLF).

The major difference between the modelling and experimental extraction conditions is the presence of the metal chelating species glycine and citrate in the SLF: all experimental extractions were carried out in the presence of these species, whereas for the modelling, only the MINTEQ and OLI databases allowed the effect of these species to be modelled. We can see from Figure 1, for example, that the presence of glycine/citrate shows a significant increase in the bioavailability of $\mathrm{Cu}$. Both MINTEQ and OLI have a large, predicted increase in bioaccessibility at high $\mathrm{S} / \mathrm{L}$ ratios for $\mathrm{Cu}$ and, to a smaller extent, $\mathrm{Zn}$. From Table 4, it is 
clear that for both OLI and MINTEQ, at an S/L ratio of 1/500 (pH 7.0), the diglycinate complex of $\mathrm{Cu}$ is the most significant aqueous $\mathrm{Cu}$ species; and for $\mathrm{Zn}$, the $\mathrm{Zn}$-citrate complexes make a significant contribution to the aqueous stability (though the $\mathrm{Zn}^{2+}$ ion and carbonate complexes are also significant components). Manganese is also predicted to be solubilised by citrate, though the effect is marginal at an $\mathrm{S} / \mathrm{L}$ ratio of $1 / 500$. The results of the statistical evaluation in Table 5 show a better performance for the prediction of copper concentrations when citrate and glycine are included in OLI and MINTEQ, though this improvement is not evident for any of the other PTEs studied.

The discrepancy between the predicted and experimental bioaccessibilities for many of the PTEs is likely to be explained by the underlying mineralogy of the PTEs components in NIST 2710a, as well as the possibility of surface complexation and surface occlusion. Many authors have discussed the role of mineralogy as a determining factor in bioaccessibility and have identified the minerals that are likely to be associated with the highest bioaccessibilities, such as chlorides and sulphates [3,8,16-23,41]. However, for most particulate samples, a detailed mineralogy will not be available and so cannot be reflected in the modelling, unlike for specific sources such as in the modelling work carried out by Thomas et al. [16] and Helser et al. [17]. Moreover, notwithstanding the mineralogy, we do know from experimental studies that much higher bioaccessibilities are possible when using the lower $\mathrm{pH}$ ALF [14,15], even up to $100 \%$ for $\mathrm{Cu}, \mathrm{Pb}$ and $\mathrm{As}$ [15], and so it is likely that other factors are also involved. There is good evidence of surface occlusion being a factor in SLFs, particularly for $\mathrm{Pb}$ containing particles (galena particles from mine waste), where, over the course of $24 \mathrm{~h}$, a 2-5 $\mu \mathrm{m}$ thick surface coating of lead phosphate develops, through intermediate Si-P-Al-O phases. A similar process has been observed by Kastury et al. in neutral Hatch's solution, where a 3-4 $\mu \mathrm{m}$ thick O-Pb-Ca-P-Si-Al-Fe forms on $\mathrm{PM}_{10}$ particles taken from areas of mining/smelting [20]. Such surface occlusion will inhibit further interaction between the particles and the SLF. Table 4 shows that metal phosphates are likely to precipitate from solution, including for $\mathrm{Pb}$ (MINTEQ), supporting the plausibility that such reactions might also occur at the particle surface. In addition, there is the potential of surface adsorption of released PTE species, including specific surface complexation processes such as between iron minerals (oxides and oxohydroxysulphates) and $\mathrm{AsO}_{4}{ }^{3-}$ and $\mathrm{Pb}^{2+}[16]$.

\subsubsection{Comparison of Modelled and Predicted Bioaccessibilities for NIST 1648a and BCR 038}

Figure 2 shows similar trends to Figure 1 in terms of the modelling results, though in this case, for comparison to the literature study of Caboche et al. [8], only data for $\mathrm{Pb}$ and $\mathrm{Zn}$ are available. The comparison of modelled concentrations for NIST 1648a and BCR 038 allows us to observe the effect of particulate PTE concentration on bioaccessibility because of the approximately ten-fold difference in concentrations of $\mathrm{Pb}$ and $\mathrm{Zn}$ between the two standards (with NIST 1648 the higher of the two and having similar concentrations to NIST 2710a, Figure 1). In addition, taking Figures 1 and 2 together, we can see the wide range of reported experimental bioaccessibilities, particularly for $\mathrm{Zn}$.

As with the data presented in Figure 1, most of the models predict very high bioaccessibilities for $\mathrm{Pb}$ and $\mathrm{Zn}$ at the lowest $\mathrm{S} / \mathrm{L}$ ratio, with the exception of WATEQ4F and MINTEQ (with and without glycine/citrate) for Pb and WATEQ4F for the NIST 1648a Zn result. The default Thermo database in GWB 14 predicts $100 \%$ extractability at almost all S/L ratios and for all PTEs; however, we see that for $\mathrm{Zn}$ in Figure 2, the curve for the Thermo database is displaced downwards, especially for BCR 038 (to 79\%), where the concentration of $\mathrm{Zn}$ is approximately one-tenth of that for NIST 2710a and NIST 1648a. The detailed speciation output from the runs indicates that this is due to the formation of a zinc chromate precipitate. Another anomaly is the drop in Zn concentration observed at an $\mathrm{S} / \mathrm{L}$ ratio of 1/500 for NIST 1648a using the PHREEQC and OLI (without glycine/citrate) models: this is due to the predicted formation of Smithsonite $\left(\mathrm{ZnCO}_{3}\right)$.

Table 6 reports the results of the $F B_{\text {mean }}$ and NMSE analysis for the Caboche et al. comparison alone, and for a combined analysis of the $\mathrm{Pb}$ and $\mathrm{Zn}$ results for $\mathrm{BCR}$ 038, NIST 
1648a and NIST 2710a. As with the results for NIST 2710a alone (Figure 1 and Table 5), most of the parameters exceed the accepted performance criteria, except for Zn modelled using MINTEQ ( $F B_{\text {mean }}$ and NMSE both withing the performance criteria).

Table 6. Performance metrics for bioaccessibility modelling of NIST 1648a and BCR 038 [8]. Values in bold indicate 'acceptable' performance [37].

\begin{tabular}{|c|c|c|c|c|c|c|c|}
\hline $\begin{array}{c}\text { Statistical Measure } \\
\text { and Metal }\end{array}$ & $\begin{array}{c}\text { GWB } \\
\text { Thermo }\end{array}$ & MINTEQ & $\begin{array}{l}\text { MINTEQ + } \\
\text { gly. and citr. }\end{array}$ & PHREEQC & WAT4QF & $\begin{array}{l}\text { OLI + gly. } \\
\text { and citr. }\end{array}$ & OLI \\
\hline \multicolumn{8}{|l|}{$F B_{\text {mean }}$} \\
\hline $\mathrm{Pb}$ & -1.68 & 0.78 & 0.98 & -1.58 & 0.84 & -1.42 & -1.42 \\
\hline $\mathrm{Pb}$ (all) & -1.72 & 0.87 & 1.06 & -1.62 & 0.93 & -1.38 & -1.37 \\
\hline $\mathrm{Zn}$ & -0.58 & -0.18 & -0.50 & -0.70 & 0.75 & -0.67 & -0.62 \\
\hline Zn (all) & -0.81 & -0.41 & -0.72 & -0.90 & 0.66 & -0.88 & -0.84 \\
\hline \multicolumn{8}{|l|}{ NMSE } \\
\hline $\mathrm{Pb}$ & 9.72 & 4.64 & 5.22 & 8.75 & 5.01 & 10.81 & 10.84 \\
\hline $\mathrm{Pb}$ (all) & 11.50 & 4.75 & 5.40 & 9.40 & 5.15 & 10.40 & 10.45 \\
\hline $\mathrm{Zn}$ & 0.44 & 1.20 & 0.79 & 0.72 & 5.78 & 0.63 & 0.65 \\
\hline Zn (all) & 0.99 & 1.54 & 1.24 & 1.25 & 5.41 & 1.16 & 1.21 \\
\hline
\end{tabular}

The reasons for the discrepancies between predicted and experimentally determined bioaccessibilities in SLF will be the same as discussed for our work on NIST 2710a, though in the case of the comparisons with the results of Caboche et al. [8], we can see that such discrepancies extend to $S / L$ ratios of $1 / 20,000$ and $1 / 50,000$ (our own work has a lowest $\mathrm{S} / \mathrm{L}$ ratio of $1 / 4000)$.

\subsection{Effect of $p H$}

As the deposition of particulate matter in the lungs is likely to alter the local $\mathrm{pH}$ of the lung fluid, it was important to carry out a series of runs in which the effect of $\mathrm{pH}$ was investigated for the range of values observed in our modelling studies. Figure 3 shows bioaccessibility profiles for PTEs in NIST 2710a over the $\mathrm{pH}$ range of 6-7.4, modelled using MINTEQ (with glycine and citrate) and OLI. It is evident that whilst there is relatively little effect of $\mathrm{pH}$ on the extractabilities of As (both oxidation states were modelled, though only $\mathrm{As}(\mathrm{V})$ is shown), $\mathrm{Cu}$ and $\mathrm{Zn}$, there is a more significant effect for $\mathrm{Mn}$ and $\mathrm{Pb}$. For $\mathrm{Pb}$, modelled using OLI, bioaccessibilities greater than $60 \%$ are predicted at $\mathrm{S} / \mathrm{L}$ ratios of 1/50,000; however, lower $\mathrm{pHs}$ result in reduced bioaccessibilities (excluding $\mathrm{S} / \mathrm{L}$ ratios of $1 / 30$ and 1/500). For Pb modelled using MINTEQ, there is a less clear relationship, with the profiles appearing more similar than for OLI. From the speciation output from the OLI runs, the principle difference accounting for the increased aqueous concentration of $\mathrm{Pb}$ is the increased abundance of soluble $\mathrm{Pb}\left(\mathrm{CO}_{3}\right)_{2}{ }^{2-}$ at higher pHs. For $\mathrm{Mn}$, modelling results for both OLI and MINTEQ show a higher bioaccessibility at lower $\mathrm{pHs}$. The output from the OLI runs indicates that at the lower $\mathrm{pHs}$, there is an increased abundance of the three principal aqueous species, $\mathrm{Mn}$-citrate ${ }^{-}, \mathrm{Mn}^{2+}$ and $\mathrm{MnCl}^{+}$, most probably due to $\mathrm{pH}$-dependent competitive interactions with other PTEs and matrix components. We know from the literature that $\mathrm{pH}$ has the potential to play a major role in bioaccessibility, with experimental results showing high bioaccessibilities for $\mathrm{Pb}$, As and $\mathrm{Zn}$ when using ALF ( $\mathrm{pH} 4.5$ ) [14,15]. In the case of ALF, this may be due to the increased formation of soluble metal chloride complexes at the lower $\mathrm{pH}$, a phenomenon that also seems to partially account for the changes in Mn solubility. 


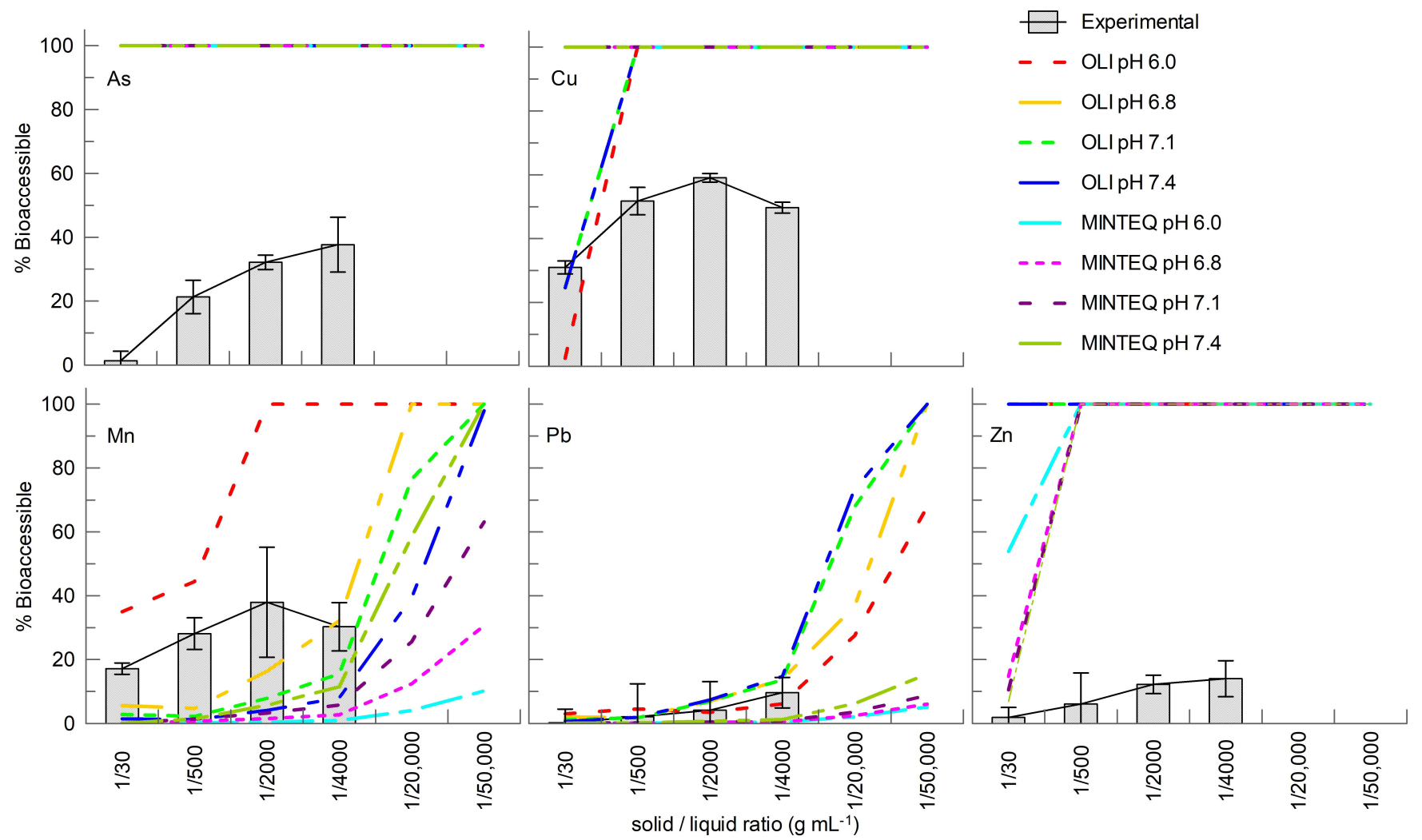

Figure 3. Influence of $\mathrm{pH}$ on observed against modelled PTE\% bioaccessibilities for NIST 2710a. Modelling was carried out only for MINTEQ (+gly. and citr.) and OLI (+gly. and citr.), at the pHs specified in the legend.

\section{Conclusions}

In this paper, we have evaluated whether aqueous chemical modelling can allow a better understanding of the underlying chemical factors influencing PTE inhalation bioaccessibility from airborne particulate matter. Such an approach can be used to supplement experimental techniques that are integral to the health risk assessment of PTE exposure by inhalational routes. This is important because experimental bioaccessibilities for $\mathrm{As}, \mathrm{Cu}$, $\mathrm{Pb}, \mathrm{Mn}$ and $\mathrm{Zn}$ in neutral SLF vary considerably, and we need to understand the reasons for this variability. We have shown that aqueous chemical modelling may provide useful insights into the components of SLF that aid the solubilisation of the PTEs.

One of the most important insights arising from the work is that, when modelled with five different aqueous chemical thermochemical databases, there was a consensus amongst the models that at the lowest $\mathrm{S} / \mathrm{L}$ ratios (greatest dilutions), $\mathrm{As}, \mathrm{Cu}, \mathrm{Pb}, \mathrm{Mn}$ and $\mathrm{Zn}$ could be up to $100 \%$ bioaccessible. Mineralogy, surface occlusion, surface complexation and adsorption are the likely explanations for the variability in observed bioaccessibility, and for the discrepancy between modelled and experimental results. The models used do allow for surface adsorption and specific minerals to be included; however, in most cases, the mineralogy of modelled particles will be unknown and so it will not be possible to include these aspects in the model. Nevertheless, a conservative approach to risk assessment might be to assume $100 \%$ bioaccessibility on the basis of the uncertainty of how the S/L ratio and residence time will vary during the lifetime of the particle in the respiratory system, and the difficulty in determining a detailed mineralogy for the PTEs of concern.

From the evaluation of the modelled results using the statistical performance measures, $F B_{\text {mean }}$ and NMSE, none of the models stood out in terms of meeting the performance criteria across the range of PTEs, though some did meet both of the performance criteria for individual PTEs. These were the GWB Thermo database for $\mathrm{Cu}$ and WATQ4F for $\mathrm{Zn}$ 
for our NIST 2710a experimental results, and Zn modelled using MINTEQ for the Caboche et al. [8] comparison. OLI also appears to give a reasonable performance for $\mathrm{Pb}$ and $\mathrm{Zn}$.

The models did predict the experimentally observed increase in bioaccessibility for more dilute S/L ratios, and the importance of glycine and citrate in solubilising metals (OLI and MINTEQ). The modelling confirms that $\mathrm{pH}$ is an important determinant of bioaccessibility, particularly for $\mathrm{Pb}$ and $\mathrm{Mn}$ over a narrow range of possible $\mathrm{pH}$ values that might occur as a result of particulate matter interaction with lung fluid, especially at the highest S/L ratios. Our experimental bioaccessibility determinations using NIST 2710a showed that DPPC was not a significant factor affecting bioaccessibility.

Overall, this study provides insights into the likely aqueous- and solid-phase PTE speciation that occurs in a basic model that excludes the influence of mineralogy and surface interactions. We propose to extend the work to include aspects of mineralogy and surface adsorption. As far as we are aware, this is the first comparative study to have been carried out on such a wide range of aqueous chemistry thermochemical models.

Author Contributions: Conceptualisation, M.E.D., J.A.E. and J.R.D.; methodology, J.A.E., P.M.A. and J.R.D.; software, M.E.D.; validation, M.E.D., P.M.A. and J.R.D.; formal analysis, M.E.D., P.M.A. and J.R.D.; investigation, M.E.D. and P.M.A.; resources, M.E.D., J.A.E., P.M.A. and J.R.D.; data curation, M.E.D. and J.R.D.; writing—original draft preparation, M.E.D.; writing—review and editing, M.E.D., J.A.E., P.M.A. and J.R.D.; visualisation, M.E.D.; supervision, M.E.D., J.A.E., and J.R.D.; project administration, M.E.D., J.A.E., and J.R.D.; funding acquisition, M.E.D., J.A.E., and J.R.D. All authors have read and agreed to the published version of the manuscript.

Funding: We are grateful to Northumbria University for funding the experimental work (granted to P.M.A.). This research received no external funding.

Institutional Review Board Statement: Not applicable.

Informed Consent Statement: Not applicable.

Data Availability Statement: The data presented in this study are available on request from the corresponding author.

Conflicts of Interest: The authors declare no conflict of interest.

\section{References}

1. Liu, X.; Ouyang, W.; Shu, Y.; Tian, Y.; Feng, Y.; Zhang, T.; Chen, W. Incorporating bioaccessibility into health risk assessment of heavy metals in particulate matter originated from different sources of atmospheric pollution. Environ. Pollut. $2019,254,113113$. [CrossRef] [PubMed]

2. Entwistle, J.A.; Hursthouse, A.S.; Reis, P.A.M.; Stewart, A.G. Metalliferous mine dust: Human health impacts and the potential determinants of disease in mining communities. Curr. Pollut. Rep. 2019, 5, 67-83. [CrossRef]

3. Hettiarachchi, E.; Paul, S.; Cadol, D.; Frey, B.; Rubasinghege, G. Mineralogy controlled dissolution of uranium from airborne dust in simulated lung fluids (slfs) and possible health implications. Environ. Sci. Tech. Lett. 2018, 6, 62-67. [CrossRef] [PubMed]

4. Dean, J.R.; Elom, N.I.; Entwistle, J.A. Use of simulated epithelial lung fluid in assessing the human health risk of pb in urban street dust. Sci. Total Environ. 2017, 579, 387-395. [CrossRef]

5. Davies, N.M.; Feddah, M.R. A novel method for assessing dissolution of aerosol inhaler products. Int. J. Pharm. 2003, 255, 175-187. [CrossRef]

6. Lay, J.C.; Bennett, W.D.; Kim, C.S.; Devlin, R.B.; Bromberg, P.A. Retention and intracellular distribution of instilled iron oxide particles in human alveolar macrophages. Am. J. Resp. Cell Mol. 1998, 18, 687-695. [CrossRef]

7. Ren, H.; Yu, Y.; An, T. Bioaccessibilities of metal (loid) s and organic contaminants in particulates measured in simulated human lung fluids: A critical review. Environ. Pollut. 2020, 265, 115070. [CrossRef]

8. Caboche, J.; Perdrix, E.; Malet, B.; Alleman, L.Y. Development of an in vitro method to estimate lung bioaccessibility of metals from atmospheric particles. J. Environ. Monit. 2011, 13, 621-630.

9. Kelly, F.J.; Fussell, J.C. Role of oxidative stress in cardiovascular disease outcomes following exposure to ambient air pollution. Free Radical Biol. Med. 2017, 110, 345-367. [CrossRef]

10. Twining, J.; McGlinn, P.; Loi, E.; Smith, K.; Gieré, R. Risk ranking of bioaccessible metals from fly ash dissolved in simulated lung and gut fluids. Environ. Sci. Technol. 2005, 39, 7749-7756. [CrossRef]

11. Tsuda, A.; Henry, F.S.; Butler, J.P. Particle transport and deposition: Basic physics of particle kinetics. Compr. Physiol. 2011, 3, $1437-1471$. 
12. Boisa, N.; Elom, N.; Dean, J.R.; Deary, M.E.; Bird, G.; Entwistle, J.A. Development and application of an inhalation bioaccessibility method (ibm) for lead in the pm10 size fraction of soil. Environ. Int. 2014, 70, 132-142. [CrossRef] [PubMed]

13. Kastury, F.; Smith, E.; Juhasz, A.L. A critical review of approaches and limitations of inhalation bioavailability and bioaccessibility of metal (loid) s from ambient particulate matter or dust. Sci. Total Environ. 2017, 574, 1054-1074. [CrossRef] [PubMed]

14. Pelfrêne, A.; Cave, M.R.; Wragg, J.; Douay, F. In vitro investigations of human bioaccessibility from reference materials using simulated lung fluids. Int. J. Environ. Res. 2017, 14, 112. [CrossRef] [PubMed]

15. Meza-Figueroa, D.; Barboza-Flores, M.; Romero, F.M.; Acosta-Elias, M.; Hernández-Mendiola, E.; Maldonado-Escalante, F.; Pérez-Segura, E.; González-Grijalva, B.; Meza-Montenegro, M.; García-Rico, L. Metal bioaccessibility, particle size distribution and polydispersity of playground dust in synthetic lysosomal fluids. Sci. Total Environ. 2020, 713, 136481. [CrossRef] [PubMed]

16. Thomas, A.N.; Root, R.A.; Lantz, R.C.; Sáez, A.E.; Chorover, J. Oxidative weathering decreases bioaccessibility of toxic metal (loid) $\mathrm{s}$ in pm10 emissions from sulfide mine tailings. GeoHealth 2018, 2, 118-138. [CrossRef] [PubMed]

17. Helser, J.; Cappuyns, V. Trace elements leaching from pbzn mine waste (plombières, belgium) and environmental implications. J. Geochem. Explor. 2020, 220, 106659. [CrossRef]

18. Palumbo-Roe, B.; Wragg, J.; Cave, M.R.; Wagner, D. Effect of weathering product assemblages on pb bioaccessibility in mine waste: Implications for risk management. Environ. Sci. Pollut. Res. 2013, 20, 7699-7710. [CrossRef]

19. Ettler, V.; Šebek, O.; Grygar, T.; Klementová, M.; Bezdička, P.; Slavíková, H. Controls on metal leaching from secondary pb smelter air-pollution-control residues. Environ. Sci. Technol. 2008, 42, 7878-7884. [CrossRef]

20. Kastury, F.; Karna, R.R.; Scheckel, K.G.; Juhasz, A.L. Correlation between lead speciation and inhalation bioaccessibility using two different simulated lung fluids. Environ. Pollut. 2020, 23, 114609. [CrossRef]

21. Wragg, J.; Klinck, B. The bioaccessibility of lead from welsh mine waste using a respiratory uptake test. J. Environ. Sci. Health A 2007, 42, 1223-1231. [CrossRef] [PubMed]

22. Ettler, V.; Johan, Z.; Baronnet, A.; Jankovský, F.; Gilles, C.; Mihaljevič, M.; Šebek, O.; Strnad, L.; Bezdička, P. Mineralogy of air-pollution-control residues from a secondary lead smelter: Environmental implications. Environ. Sci. Technol. 2005, 39, 9309-9316. [CrossRef] [PubMed]

23. Vítková, M.; Ettler, V.; Šebek, O.; Mihaljevič, M.; Grygar, T.; Rohovec, J. The ph-dependent leaching of inorganic contaminants from secondary lead smelter fly ash. J. Haz. Mat. 2009, 167, 427-433. [CrossRef] [PubMed]

24. Zhang, Y.; Jiang, J.; Maozhe, C. Minteq modeling for evaluating the leaching behavior of heavy metals in mswi fly ash. J. Environ. Sci. 2008, 20, 1398-1402. [CrossRef]

25. McGivney, E.; Gustafsson, J.P.; Belyazid, S.; Zetterberg, T.; Löfgren, S. Assessing the impact of acid rain and forest harvest intensity with the hd-minteq model-soil chemistry of three swedish conifer sites from 1880 to 2080. Soil 2019, 5, 63-77. [CrossRef]

26. Parkhurst, D.L.; Appelo, C. Description of Input and Examples for Phreeqc Version 3: A Computer Program for Speciation, Batch-Reaction, One-Dimensional Transport, and Inverse Geochemical Calculations; U.S. Geological Survey: Reston, VA, USA, 2013.

27. Peterson, S.; Hostetler, C.; Deutsch, W.; Cowan, C. Minteq User's Manual; Pacific Northwest Lab.: Richland, WA, USA, 1987.

28. Ball, J.W.; Nordstrom, D.K. Wateq4f-User's Manual with Revised Thermodynamic Data Base and Test. Cases for Calculating Speciation of Major, Trace and Redox Elements in Natural Waters; U.S. Geological Survey: Reston, VA, USA, 1991.

29. Bethke, C.M.; Farrell, B.; Sharifi, M. The Geochemist's Workbench Release 14, Gwb Essentials Guide; Aqueous Solutions LLC: Champaign, IL, USA, 2020.

30. OLI Systems. A Guide to Using Oli Studio Version 9.5; OLI Systems Inc.: Ceder Knolls, NJ, USA, 2016.

31. Davies, L.A.; Dargue, A.; Dean, J.R.; Deary, M.E. Use of $24 \mathrm{khz}$ ultrasound to improve sulfate precipitation from wastewater. Ultrason. Sonochem. 2015, 23, 424-431. [CrossRef]

32. Govan, P. Manipulating Aqueous Chemistry Environments in Extractive Metallurgy. Ph.D. Thesis, University of Cape Town, Cape Town, South Africa, 2010.

33. Anawati, J.; Azimi, G. Recovery and separation of phosphorus as dicalcium phosphate dihydrate for fertilizer and livestock feed additive production from a low-grade phosphate ore. RSC Adv. 2020, 10, 38640-38653. [CrossRef]

34. Okorie, A.; Entwistle, J.; Dean, J.R. The optimization of microwave digestion procedures and application to an evaluation of potentially toxic element contamination on a former industrial site. Talanta 2010, 82, 1421-1425. [CrossRef]

35. Bethke, C.M. Geochemical and Biogeochemical Reaction Modeling; Cambridge University Press: Cambridge, UK, 2007.

36. Deary, M.E.; Uapipatanakul, S. Evaluation of the performance of adms in predicting the dispersion of sulfur dioxide from a complex source in Southeast Asia: Implications for health impact assessments. Air Qual. Atmos. Health 2014, 7, 381-399. [CrossRef]

37. Patryla, L.; Galeriua, D. Statistical Performances Measures-Models Comparison; CEA: Paris, France, 2011.

38. Li, S.-W.; Li, H.-B.; Luo, J.; Li, H.-M.; Qian, X.; Liu, M.-M.; Bi, J.; Cui, X.-Y.; Ma, L.Q. Influence of pollution control on lead inhalation bioaccessibility in pm2. 5: A case study of 2014 Youth Olympic Games in Nanjing. Environ. Int. 2016, $94,69-75$. [CrossRef]

39. Martin, R.; Dowling, K.; Nankervis, S.; Pearce, D.; Florentine, S.; McKnight, S. In vitro assessment of arsenic mobility in historical mine waste dust using simulated lung fluid. Environ Geochem. Health 2018, 40, 1037-1049. [CrossRef] [PubMed]

40. Ebdon, L.; Fitzpatrick, S.; Foulkes, M.E. The speciation of arsenic compounds. Chem Anal. Warsaw 2002, 47, 179-188.

41. Vodyanitskii, Y.N. Determination of the oxidation states of metals and metalloids: An analytical review. Eurasian Soil Sci. 2013, 46, 1139-1149. [CrossRef] 